\title{
A Study on the Activation Strategy for Female Maritime Officers using AHP
}

\author{
† Woo-Lee Jeong
}

+ Research Institute of Maritime Industry of Korea Maritime and Ocean University, Busan 606-791, Republic of Korea

\begin{abstract}
As the ratio of women's socioeconomic participation expanded, this phenomenon appeared maritime industry. The advent of female seafarers will be the solution for the shortage of seafarer as well as for women's employment instability all over the world. This paper analyzed the state of present female maritime officers and suggested the activation strategy which preliminary female officers advised by AHP and STOW analysis. This paper finds to strengthen their superior aspects like professional knowedge, practical ability, job performance, improve the education system by gender, strengthen the career path and transform the policy for them by sensitively external changes by government and education institutions.
\end{abstract}

Key words : Maritime University, Female Maritime Officer, Seafarer, AHP, SWOT, Activation Strategy

\section{Introduction}

Since the latter half of 1990s, shipping companies have been expanding employment of female seafarers although it had been considered previously that the ship was a male-dominant field. However according to the results of a survey on female seafarers conducted by ILO in 2003, a major ship type in which female seafarers worked was ferry and its ratio was $68 \%$. Following this, the ratio of cruise ship was 26\%. Both ship types account for about $94 \%$ and this means that the ratio of females in charge of maritime cargo transportation was merely 6\%(JITI \& NF, 2010). Also, if compared the ratio of officers and ratings between all genders and female only, the ratio of female officers is just $7 \%$ although the ratio of male officers is $42 \%$. These facts mean that the working places on board for female seafarers are still very limited relatively.

In this context, this paper suggests strategy for preliminary female officers to applicate countermeasures for shortage seafarers in the near future by their voice This is an area where the preliminary female officers have an important role to play. Also, in the process of building measures to activate the female officers, it is very important to make use of advantages, hold chances, overcome disadvantages, avoid threats, make feasible developing goals and adopt a suitable development strategy. Then it is necessary to study the strategy of developing the maritime industry.

\section{Present status of seafarers}

There are 2 universities, Korea maritime and ocean university(KMOU) and Mokpo maritime university(MMU), to produce outstanding female maritime officers in Korea. According to the Table 1 to 3 , they sent out 1,236 graduates from 1995 to 2013(See Table 1), and 50\% among them had been maritime officers each year for last 5years(See Table 2 and 3).

Table 1 Status of female graduation

\begin{tabular}{|c|c|c|c|c|c|c|}
\hline $\begin{array}{c}\text { Year } \\
\text { of } \\
\text { Grad. }\end{array}$ & \multicolumn{3}{|c|}{ KMOU } & \multicolumn{3}{c|}{ MMU } \\
\cline { 2 - 7 } & Nav. & Eng. & Total & Nav. & Eng. & Total \\
\hline 1995 & 1 & - & 1 & - & - & - \\
\hline 1996 & 4 & 1 & 5 & 17 & 7 & 24 \\
\hline 1997 & 5 & 1 & 6 & 10 & 3 & 13 \\
\hline 1998 & 14 & 2 & 16 & 16 & 6 & 22 \\
\hline 1999 & 17 & 6 & 23 & 23 & 3 & 26 \\
\hline 2000 & 27 & 6 & 33 & 34 & 7 & 41 \\
\hline 2001 & 38 & 11 & 49 & 37 & 14 & 51 \\
\hline 2002 & 36 & 12 & 48 & 22 & 16 & 38 \\
\hline 2003 & 17 & 3 & 20 & 17 & 14 & 31 \\
\hline 2004 & 10 & 11 & 21 & 17 & 14 & 31 \\
\hline 2005 & 13 & 7 & 20 & 21 & 19 & 40 \\
\hline 2006 & 15 & 15 & 30 & 15 & 15 & 30 \\
\hline 2007 & 12 & 18 & 30 & 17 & 14 & 31 \\
\hline 2008 & 27 & 23 & 50 & 21 & 22 & 43 \\
\hline 2009 & 22 & 23 & 45 & 17 & 17 & 34 \\
\hline 2010 & 28 & 28 & 56 & 15 & 20 & 35 \\
\hline 2011 & 29 & 29 & 58 & 23 & 18 & 41 \\
\hline 2012 & 34 & 29 & 63 & 22 & 18 & 40 \\
\hline 2013 & 23 & 25 & 48 & 20 & 23 & 43 \\
\hline Total & 372 & 250 & 622 & 364 & 250 & 614 \\
\hline & & & & & & \\
\hline
\end{tabular}

† Corresponding author, wooryj@kmou.ac.kr 051)410-4255

Note) This paper was presented on the subject of "A Study on the Reinforcement Strategy of Prospective Female Maritime Officers" in 2013 Joint Conference KINPR \& KOSME proceedings(Republic of Korea Naval Academy, 27th-28th Jun, 2013, pp. 103-107) 
Table 2 Status of employment after graduation(KMOU)

\begin{tabular}{|c|c|c|c|c|c|}
\hline Date & $\begin{array}{c}\text { Gradu } \\
\text { ates }\end{array}$ & $\begin{array}{c}\text { Emplo } \\
\text { yed }\end{array}$ & $\begin{array}{c}\text { On } \\
\text { board }\end{array}$ & Etc. & $\begin{array}{c}\text { Onboard } \\
\text { rate }\end{array}$ \\
\hline 2008.3 & 50 & 41 & 14 & 27 & $34 \%$ \\
\hline 2009.3 & 45 & 40 & 15 & 25 & $38 \%$ \\
\hline 2010.3 & 56 & 45 & 13 & 32 & $29 \%$ \\
\hline 2011.3 & 58 & 49 & 26 & 23 & $53 \%$ \\
\hline 2012.3 & 63 & 45 & 20 & 25 & $44 \%$ \\
\hline Total & 272 & 220 & 88 & 132 & $40 \%$ \\
\hline
\end{tabular}

Table 3 Status of employment after graduation(MMU)

\begin{tabular}{|c|c|c|c|c|c|}
\hline Date & $\begin{array}{c}\text { Gradu } \\
\text { ates }\end{array}$ & $\begin{array}{c}\text { Emplo } \\
\text { yed }\end{array}$ & $\begin{array}{c}\text { On } \\
\text { board }\end{array}$ & Etc. & $\begin{array}{c}\text { Onboard } \\
\text { rate }\end{array}$ \\
\hline 2008.3 & 43 & 31 & 16 & 15 & $52 \%$ \\
\hline 2009.3 & 34 & 23 & 16 & 7 & $70 \%$ \\
\hline 2010.3 & 35 & 24 & 14 & 10 & $58 \%$ \\
\hline 2011.3 & 41 & 26 & 20 & 6 & $77 \%$ \\
\hline 2012.3 & 40 & 37 & 18 & 19 & $49 \%$ \\
\hline Total & 193 & 141 & 84 & 57 & $60 \%$ \\
\hline
\end{tabular}

Even if it was estimated that the number of the world commercial fleets would increase up to 38,197 in 2020(an increase of 2,574 to the number in 2010)(See Fig.1). As for the demand of seafarers in 2020 corresponding to the above number of fleets, and additional 32,153 of officers and 46,881 of ratings would be necessary to the number of the demand in 2010. Actually the demand in 2010 is 445,055 for officer and 648,914 for ratings.

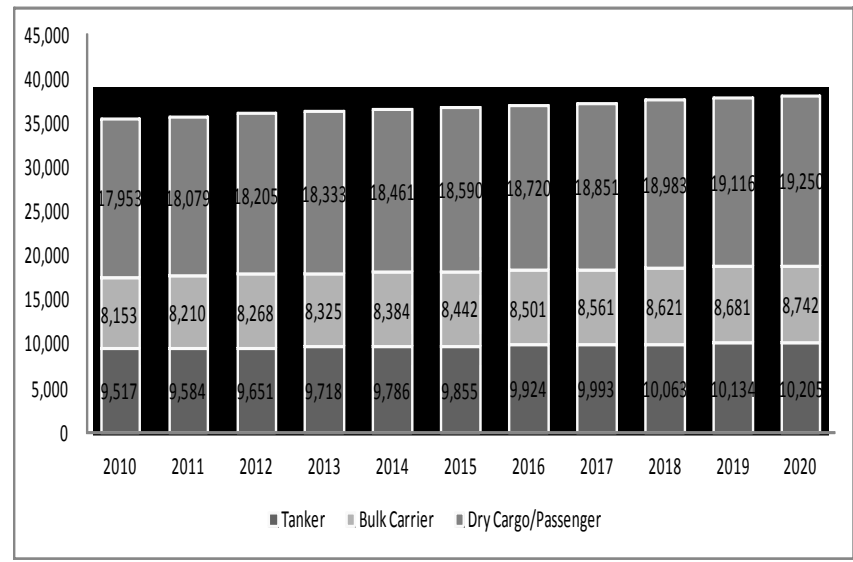

(Source : Lloyd's Register-Fairplay, 2009)

Fig. 1 Prospects for future number of the world fleets until 2020 based on the actual number of the world commercial fleets in 2010

The shortage of seafarers has become a serious concern because the world commercial fleets are continuously expanded due to the outstanding increase in world cargo movement related to new emerging countries in economy, the world financial crisis and so on. There are many kinds of solution which were suggested by many countries and organizations. One of them is the supply of quality female seafarers. Many shipping companies found no gap in working skills, competence, social competence, ability to build and maintain relationships among colleagues in ships(Jo, 2011). However there is not enough researches to train them effectively and properly.

\section{Methodology}

Successful strategic decisions provide the appropriate operational actions for the right market at the correct time. Strengths, Weaknesses, Opportunities and Threats(SWOT) analysis is generally used tool which examines strengths and weakness of organization or industry together with opportunities and threats of the marketplace environment. SWOT framework provides the basic outline in which to perform analysis of decision situations. In this paper, we proposed to enhance SWOT analysis with multicriteria decision making techniques called Analytic Hierarchy Process(AHP) to supplement the lack of determination of the importance ranking for the SWOT factors. AHP approach achieves pair wised comparisons among factors in order to prioritize them at each level of the hierarchy using the eigenvalue calculation.

The AHP method is based on three principles, structure of the model, comparative judgment of the criteria and/or alternatives, and synthesis of the priorities. In the literature, AHP has been widely used in solving many decision making problems(Lee and Walsh, 2011).

In the first step, a decision problem is structured as a hierarchy. AHP initially breaks down a complex multi-criteria decision making problem into a hierarchy of interrelated decision elements(criteria, decision alternatives). With the AHP, the objectives, decision criteria and alternatives are arranged in a hierarchical structure similar to a familiar tree(Albayrak and Erensal, 2004).

The second step is the comparison of the criteria and/or the alternatives. Once the problem has been decomposed and the hierarchy is constructed, prioritization procedure starts in order to determine the relative importance of the criteria. In each level, the criteria are compared pair wise according to their levels of influence and based on the specified criteria in the higher level. In AHP, multiple pair wise comparisons are based on a standardized comparison scale of nine level(Albayrak and Erensal, 2004).

Let $C=\left\{C_{j} \mid j=1,2, \ldots, n\right\}$ be the set of criteria. The result of the pair wise comparison on $\mathrm{n}$ criteria can be 
summarized in an $(n \times n)$ evaluation matrix $A$ in which every element $a_{i j}(i, j=1,2, \ldots, n)$ is the quotient of weights of the criteria. This pair wise comparison can be shown by a square and reciprocal matrix,(see Eq.(1)).

$$
A=\left(a_{i j}\right)_{n x n}=\left[\begin{array}{llll}
a_{11} & a_{12} & \ldots & a_{1 n} \\
a_{21} & a_{22} & & a_{2 n} \\
\cdot & \cdot & \ldots \\
\cdot & \cdot & \ldots \\
\cdot & \cdot & \cdots \\
a_{n 1} & a_{n 2} & a_{n m}
\end{array}\right]
$$

At the last step, each matrix is normalized and be found the relative weights. The relative weights are given by the right eigenvector $(\mathrm{w})$ corresponding to the largest eigenvalue $\left(\lambda_{\max }\right)$, as :

$$
A_{w}=\lambda_{\max } \cdot w
$$

If the pair wise comparisons are completely consistent, the matrix $\mathrm{A}$ has rank 1 and $\lambda_{\max }=n$. In this case, weights can be obtained by normalizing any of the rows or columns of A(Albayrak and Erensal, 2004). It should be noted that the quality of the output of the AHP is related to the consistency of the pair wise comparison judgements. The consistency is defined by the relation between the entries of $\mathrm{A}: a_{i j} \times a_{j k}=a_{i k}$ (Dagdeviren et al., 2009). The Consistency Index(CI) can be calculated, using the following formula(Saaty, 1980):

$$
C I=\frac{\lambda_{\max }-n}{n-1}
$$

Using the final consistency ratio(CR) can conclude whether the evaluations are sufficiently consistent. The CR is calculated as the ratio of the $\mathrm{CI}$ and the random index(RI), as indicated in Eq.(4). The number 0.1 is the accepted upper limit for CR. If the final consistency ratio exceeds this value, the evaluation procedure has to be repeated to improve consistency(Boraji and Yakchali, 2011).

$$
C R=\frac{C I}{R I}
$$

Table 4 Random Index(RI)

\begin{tabular}{|l|c|c|c|c|c|c|c|c|c|c|}
\hline $\mathrm{n}$ & 1 & 2 & 3 & 4 & 5 & 6 & 7 & 8 & 9 & 10 \\
\hline $\mathrm{RI}$ & 0.00 & 0.00 & 0.58 & 0.90 & 1.12 & 1.24 & 1.32 & 1.41 & 1.45 & 1.49 \\
\hline
\end{tabular}

(Source: Saaty and Vargas, 1991)

This paper refers to the data carried out from 25th to 29th March 2013 in Maritime Science of Korea Maritime and Ocean University. Total of 173 female students were surveyed, and 130 questionnaires were effective.

\subsection{External environment factors}

This paper chooses 3 factors including social climate, policy and working environment. As the detailed factors were as following. Firstly, the social climate includes the point of view on seafarers, working women and working as a female officers. Maritime industry still tends to make the headlines for negative reasons like accidents, environmental impacts, piracy, oppressive security measures leading to denial of shore leave, criminalization to fuel misconceptions and act as a disincentive to recruitment. Recently, most people prefer to working women but working as a female officer in Korea is not positive. The working places on board for female seafarers are still very limited relatively. Secondly, policy includes international policy by international organizations, governmental policy and executive policy for female officers by education institutions and shipping companies. Finally, working environment includes the specific working environment which means the independent places from the land, male-dominated environment and accommodation facilities.

\section{1) Evaluation of the external environment factors}

(1) Establishment of hierarchical structure model of the external environment factors

According to the above analysis, system evaluation model of external environment factors will be established as following Fig.2.

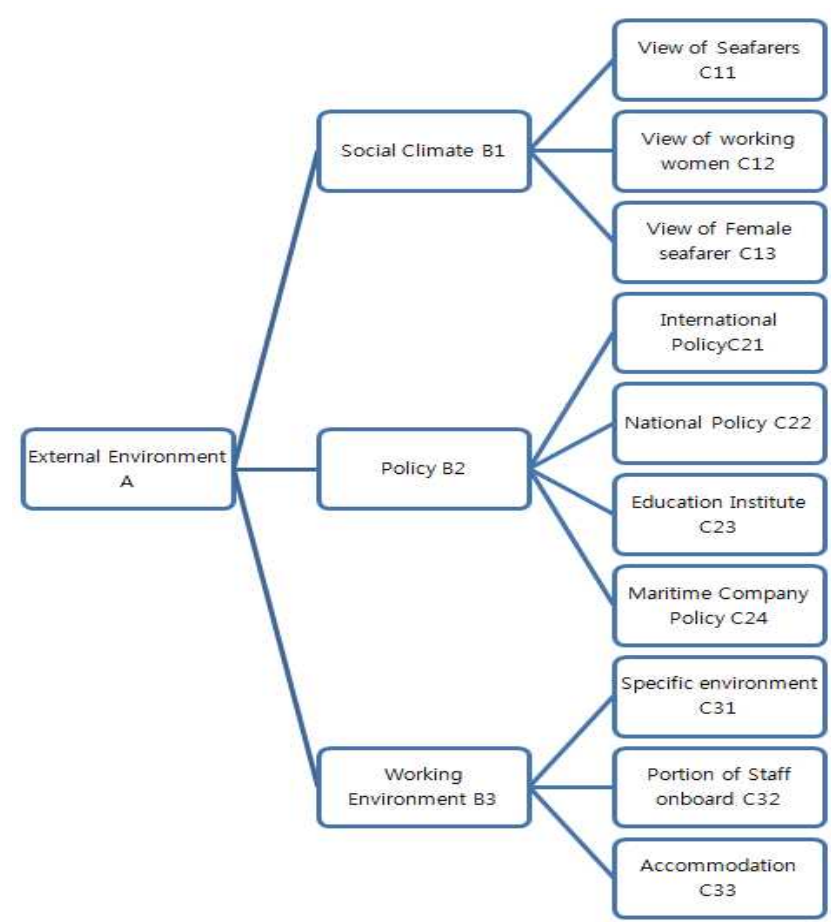

Fig. 2 Evaluation model of External Factors

(2) Establishment of matrix, calculation of weight and ranking of level 
A Study on the Activation Strategy for Female Maritime Officers using AHP

Table 5 Relative importance of $\mathrm{A}$ as compared with $\mathrm{B}$

\begin{tabular}{|c|c|c|c|c|}
\hline $\mathrm{A}$ & $B_{1}$ & $B_{2}$ & $B_{3}$ & $W_{i j}$ \\
\hline$B_{1}$ & 1.000 & 3.000 & 0.250 & 0.231 \\
\hline$B_{2}$ & 0.333 & 1.000 & 0.200 & 0.104 \\
\hline$B_{3}$ & 4.000 & 5.000 & 1.000 & 0.665 \\
\hline
\end{tabular}

Table 6 Relative importance of $B_{1}$ as compared with $\mathrm{C}$

\begin{tabular}{|c|c|c|c|c|}
\hline$B_{1}$ & $C_{11}$ & $C_{12}$ & $C_{13}$ & $W_{i j}$ \\
\hline$C_{11}$ & 1.000 & 0.333 & 4.000 & 0.284 \\
\hline$C_{12}$ & 3.000 & 1.000 & 5.000 & 0.619 \\
\hline$C_{13}$ & 0.250 & 0.200 & 1.000 & 0.096 \\
\hline
\end{tabular}

Table 7 Relative importance of $B_{2}$ as compared with $\mathrm{C}$

\begin{tabular}{|c|c|c|c|c|c|}
\hline$B_{2}$ & $C_{21}$ & $C_{22}$ & $C_{23}$ & $C_{24}$ & $W_{i j}$ \\
\hline$C_{21}$ & 1.000 & 0.333 & 2.000 & 0.333 & 0.150 \\
\hline$C_{22}$ & 3.000 & 1.000 & 3.000 & 0.500 & 0.309 \\
\hline$C_{23}$ & 0.500 & 0.333 & 1.000 & 0.333 & 0.106 \\
\hline$C_{24}$ & 3.000 & 2.000 & 3.000 & 1.000 & 0.435 \\
\hline
\end{tabular}

Table 8 Relative importance of B3 as compared with C

\begin{tabular}{|c|c|c|c|c|}
\hline$B_{3}$ & $C_{31}$ & $C_{32}$ & $C_{33}$ & $W_{i j}$ \\
\hline$C_{31}$ & 1.000 & 2.000 & 3.000 & 0.548 \\
\hline$C_{32}$ & 0.500 & 1.000 & 1.000 & 0.241 \\
\hline$C_{33}$ & 0.333 & 1.000 & 1.000 & 0.211 \\
\hline
\end{tabular}

The weights are calculated by root method, which means by using the geometric mean of each row in pair wise comparison matrix as above Table5 $\sim$ Table8. The weights are as following Table 9.

Table 9 Relative weight of A as compared with $\mathrm{C}$

\begin{tabular}{|c|c|c|c|c|}
\hline $\begin{array}{l}\text { Objecti } \\
\text { ve }\end{array}$ & $\begin{array}{l}\text { Relative } \\
\text { weight }\end{array}$ & Objecti & $\begin{array}{l}\text { Relative } \\
\text { weight }\end{array}$ & \multicolumn{2}{|l|}{$\begin{array}{l}\text { Relative weight } \\
\text { of ampared as } \\
\text { comith } \\
\text { [e }\end{array}$} \\
\hline$B_{1}$ & 0.231 & $C_{11}$ & 0.284 & 0.066 \\
\hline & & $C_{12}$ & 0.619 & 0.143 \\
\hline & & $C_{13}$ & 0.096 & 0.022 \\
\hline$B_{2}$ & 0.104 & $C_{21}$ & 0.150 & 0.016 \\
\hline & & $C_{22}$ & 0.309 & 0.032 \\
\hline & & $C_{23}$ & 0.106 & 0.011 \\
\hline$B_{3}$ & 0.665 & $C_{24}$ & 0.435 & 0.045 \\
\hline & & $C_{32}$ & 0.548 & 0.365 \\
\hline & & $C_{33}$ & 0.241 & 0.160 \\
\hline
\end{tabular}

\section{(3) Consistency test}

The relative weight of $\mathrm{A}$ as compared with $B=\left(B_{1}, B_{2}, B_{3}\right)^{T}$ would be:

$$
W_{B}=\left(W_{B_{1}}, W_{B_{2}}, W_{B_{3}}\right)^{T}=(0.231,0.104,0.665)^{T}
$$

The next step is to compute the maximum eigen value and perform consistency's test.

$$
A_{-A} W_{B}=\left[\begin{array}{ccc}
1 & 3 & 0.250 \\
0.333 & 1 & 0.2 \\
4 & 5 & 1
\end{array}\right]\left|\begin{array}{l}
0.231 \\
0.104 \\
0.665
\end{array}\right|=\mid \begin{aligned}
& 0.709 \\
& 0.314 \\
& 2.109
\end{aligned}
$$

(5)

$$
\begin{aligned}
& \lambda_{\max }=\sum_{i=1}^{n} \frac{\left(A-{ }_{B} W_{B}\right)_{i}}{n W_{B i}}=3.087 \\
& C I=\frac{\lambda_{\max }-n}{n-1}=0.0435
\end{aligned}
$$

According to the table4, the value of RI would be:

$$
\begin{aligned}
& R I=0.58 \\
& C R=\frac{C I}{R I}=0.075<0.1
\end{aligned}
$$

The consistency of matrix is acceptable.

The relative weight of $B_{1}$ as compared with $C_{1}=\left(C_{11}, C_{12}, C_{13}\right)^{T}$ would be:

$$
\begin{aligned}
& W_{C_{1}}=\left(W_{C_{11}}, W_{C_{12}}, W_{C_{13}}\right)^{T}=(0.284,0.619,0.096)^{T} \\
& \lambda_{\max }=3.087 \\
& C I=0.043 \\
& R I=0.58 \\
& C R=0.075<0.1
\end{aligned}
$$

The consistency of matrix is acceptable.

The relative weight of $B_{2}$ as compared with $C_{2}=\left(C_{21}, C_{22}, C_{23}, C_{24}\right)^{T}$ would be:

$$
\begin{aligned}
& W_{C_{1}}=\left(W_{C_{21}}, W_{C_{22}}, W_{C_{23}}, W_{C_{24}}\right)^{T}=(0.150,0.309,0.106,0.435)^{T} \\
& \lambda_{\max }=4.122 \\
& C I=0.0407 \\
& R I=0.90 \\
& C R=0.0452<0.1
\end{aligned}
$$

The consistency of matrix is acceptable.

The relative weight of $B_{3}$ as compared with $C_{3}=\left(C_{31}, C_{32}, C_{33}\right)^{T}$ would be:

$$
\begin{aligned}
& W_{C_{3}}=\left(W_{C_{31}}, W_{C_{32}}, W_{C_{33}}\right)^{T}=(0.548,0.241,0.211)^{T} \\
& \lambda_{\max }=3.018 \\
& C I=0.009 \\
& R I=0.58 \\
& C R=0.0155<0.1
\end{aligned}
$$

The consistency of matrix is acceptable.

The relative weight of $\mathrm{A}$ as compared with $C=\left(C_{11}, C_{12}, C_{13}, C_{21}, C_{22}, C_{23}, C_{24}, C_{31}, C_{32}, C_{33}\right)^{T}$ would be: $W_{C}=\left(W_{C_{11}}, W_{C_{12}}, W_{C_{13}}, W_{C_{21}}, W_{C_{22}}, W_{C_{23}}, W_{C_{24}}, W_{C_{31}}, W_{C_{32}}, W_{C_{33}}\right)^{T}$

$(0.066,0.143,0.022,0.016,0.032,0.011,0.045,0.365,0.160,0.140)^{T}$ $C I=(0.231 \times 0.043)+(0.104 \times 0.0407)+(0.665 \times 0.009)=0.020$ 
$R I=(0.231 \times 0.58)+(0.104 \times 0.90)+(0.665 \times 0.58)=0.6133$

$C R=0.0326<0.1$

The consistency of matrix is acceptable.

(4) Choosing and analysis of $\mathrm{O}, \mathrm{T}$ from external environment factor system

In this part, this paper makes reference to importance scores of strategic decision to activate female officers which are given by survey. Then, combine the importance values, table 10, with the weights by using the Delphi method and gained the compositive weights of external environment factors. The Delphi method is a structured communication technique, originally developed as a systematic, interactive forecasting method which relies on a panel of experts(Wikipedia, 2013).

Table 10 Importance values

\begin{tabular}{|c|l|}
\hline Score & \multicolumn{1}{|c|}{ Importance } \\
\hline-5 & Not at all important \\
\hline-3 & Somewhat important \\
\hline 0 & Fairly important \\
\hline 3 & Very important \\
\hline 5 & Critical \\
\hline
\end{tabular}

Table 11 Evaluation of external environment factors

\begin{tabular}{|c|c|c|c|}
\hline $\begin{array}{c}\text { External } \\
\text { environment }\end{array}$ & Weight & $\begin{array}{c}\text { Importance } \\
\text { score }\end{array}$ & $\begin{array}{c}\text { Compositive } \\
\text { weight }\end{array}$ \\
\hline$C_{11}$ & 0.066 & -3 & -0.20 \\
\hline$C_{12}$ & 0.143 & 5 & 0.72 \\
\hline$C_{13}$ & 0.022 & -5 & -0.11 \\
\hline$C_{21}$ & 0.016 & 3 & 0.05 \\
\hline$C_{22}$ & 0.032 & -3 & -0.10 \\
\hline$C_{23}$ & 0.011 & -3 & -0.03 \\
\hline$C_{24}$ & 0.045 & -5 & -0.23 \\
\hline$C_{31}$ & 0.365 & -5 & -1.82 \\
\hline$C_{32}$ & 0.160 & 0 & 0.00 \\
\hline$C_{33}$ & 0.140 & -1 & -0.14 \\
\hline
\end{tabular}

There are 10 external environment factors in preliminary female officers opinions, the factor of which the compositive weight is less than \pm 0.1 is secondary influence factor. There are 3 secondary influence factors and they are debarred in Table11. The rest factors are major influence factors. They are

$C_{11}(-0.20), C_{12}(0.72), C_{13}(-0.11), C_{22}(-0.10), C_{24}(-0.23), C_{31}(-1.82)$, $C_{33}(-0.14)$.

$C_{12}(0.72)$ is chosen to be $\mathrm{O}$ (opportunities)

$C_{11}(-0.20), C_{13}(-0.11), C_{22}(-0.10), C_{24}(-0.23), C_{31}(-1.82), C_{33}(-0.14)$ are chosen to be $\mathrm{T}$ (threats) as following Table12.
Table 12 Analysis of external environmental factors

\begin{tabular}{|l|l|}
\hline \multicolumn{2}{|l|}{ Opportunity } \\
\hline Strategic Factors & \multicolumn{1}{c|}{ Remark } \\
\hline $\begin{array}{l}\text { View of working } \\
\text { women }\end{array}$ & $\begin{array}{l}\text { More and more women are } \\
\text { entering the workforce Most } \\
\text { people think women are working } \\
\text { as a matter of course. }\end{array}$ \\
\hline \multicolumn{1}{|c|}{ Threat } \\
\hline Strategic Factors & \multicolumn{1}{|c|}{ Remark } \\
\hline View of seafarers & $\begin{array}{l}\text { Most people still have negative } \\
\text { images of seafarer like accidents, } \\
\text { criminalization etc. }\end{array}$ \\
\hline $\begin{array}{l}\text { View of } \\
\text { female seafarers }\end{array}$ & $\begin{array}{l}\text { Even female seafarers tend to } \\
\text { make prejudice in private and } \\
\text { public. }\end{array}$ \\
\hline $\begin{array}{l}\text { National policy } \\
\text { for seafarers }\end{array}$ & $\begin{array}{l}\text { Government played a passive role } \\
\text { in handling the female seafarers } \\
\text { for a long time. They need to } \\
\text { handle the magnificent female } \\
\text { seafarers in maritime industry. }\end{array}$ \\
\hline $\begin{array}{l}\text { Employment policy } \\
\text { of shipping } \\
\text { company }\end{array}$ & $\begin{array}{l}\text { Most shipping companies are } \\
\text { reluctant to hire female officers } \\
\text { because they do not want make } \\
\text { miscellaneous things onboard. }\end{array}$ \\
\hline $\begin{array}{l}\text { Specific } \\
\text { environment }\end{array}$ & $\begin{array}{l}\text { Working onboard is totally } \\
\text { independent places from family, } \\
\text { friends and society. }\end{array}$ \\
\hline $\begin{array}{l}\text { As aforementioned, ships is } \\
\text { suitable to working men for a } \\
\text { facilities } \\
\text { long time. Some small-sized are } \\
\text { bathroom for women. }\end{array}$ \\
\hline
\end{tabular}

\subsection{Internal environment factors}

In this part, I choose 4 factors including biological difference, working potential, job performance and female nature factors.

1) Evaluation of the internal environment factors

(1) Establishment of hierarchical structure model of the internal environment factors

According to the above analysis, system evaluation model of internal environment factors will be established as Fig.3.

(2) Establishment of matrix, calculation of weight and ranking of level

Table 13 Relative weight of $\mathrm{O}$ as compared with $\mathrm{P}$

\begin{tabular}{|c|c|c|c|c|c|}
\hline $\mathrm{O}$ & $P_{1}$ & $P_{2}$ & $P_{3}$ & $P_{4}$ & $W_{i j}$ \\
\hline$P_{1}$ & 1.000 & 0.333 & 0.250 & 0.500 & 0.093 \\
\hline$P_{2}$ & 3.000 & 1.000 & 0.500 & 3.000 & 0.325 \\
\hline$P_{3}$ & 4.000 & 2.000 & 1.000 & 1.000 & 0.373 \\
\hline$P_{4}$ & 2.000 & 0.333 & 1.000 & 1.000 & 0.209 \\
\hline
\end{tabular}


A Study on the Activation Strategy for Female Maritime Officers using AHP

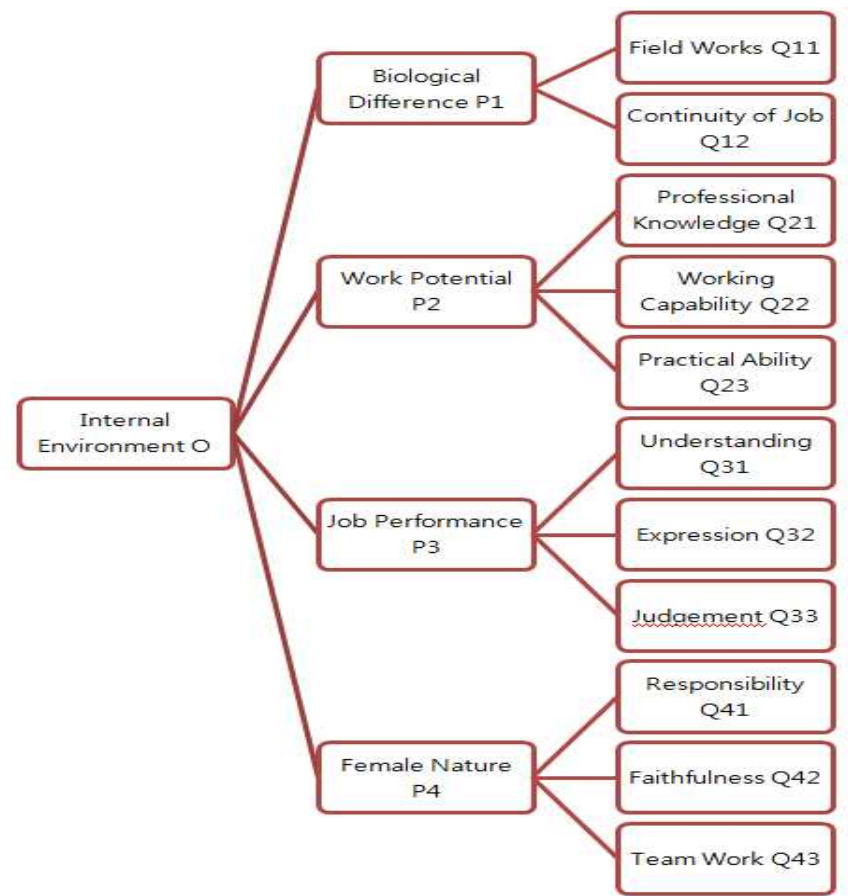

Fig. 3 Evaluation model of Internal Factors

Table 14 Relative importance of $P_{1}$ as compared with Q

\begin{tabular}{|c|c|c|c|}
\hline$P_{1}$ & $Q_{11}$ & $Q_{12}$ & $W_{i j}$ \\
\hline$Q_{11}$ & 1.000 & 0.200 & 0.167 \\
\hline$Q_{12}$ & 5.000 & 1.000 & 0.833 \\
\hline
\end{tabular}

Table 15 Relative importance of $P_{2}$ as compared with Q

\begin{tabular}{|c|c|c|c|c|}
\hline$P_{2}$ & $Q_{21}$ & $Q_{22}$ & $Q_{23}$ & $W_{i j}$ \\
\hline$Q_{21}$ & 1.000 & 0.200 & 0.333 & 0.115 \\
\hline$Q_{22}$ & 5.000 & 1.000 & 1.000 & 0.480 \\
\hline$Q_{23}$ & 3.000 & 1.000 & 1.000 & 0.405 \\
\hline
\end{tabular}

Table 16 Relative importance of $P_{3}$ as compared with Q

\begin{tabular}{|c|c|c|c|c|}
\hline$P_{3}$ & $Q_{31}$ & $Q_{32}$ & $Q_{33}$ & $W_{i j}$ \\
\hline$Q_{31}$ & 1.000 & 2.000 & 3.000 & 0.525 \\
\hline$Q_{32}$ & 0.500 & 1.000 & 3.000 & 0.334 \\
\hline$Q_{33}$ & 0.333 & 0.333 & 1.000 & 0.142 \\
\hline
\end{tabular}

Table 17 Relative importance of $P_{4}$ as compared with Q

\begin{tabular}{|c|c|c|c|c|}
\hline$P_{4}$ & $Q_{41}$ & $Q_{42}$ & $Q_{43}$ & $W_{i j}$ \\
\hline$Q_{41}$ & 1.000 & 2.000 & 2.000 & 0.500 \\
\hline$Q_{42}$ & 0.500 & 1.000 & 1.000 & 0.250 \\
\hline$Q_{43}$ & 0.500 & 1.000 & 1.000 & 0.250 \\
\hline
\end{tabular}

The weights are calculated by normalizing the geometric mean of each row in pair wise comparison matrix as above Table13 Table17. The weights are as the following table 18 .
Table 18 Relative weight of $\mathrm{P}$ as compared with $\mathrm{Q}$

\begin{tabular}{|c|c|c|c|c|}
\hline $\begin{array}{l}\text { Objecti } \\
\text { ve }\end{array}$ & $\begin{array}{l}\text { Relative } \\
\text { weight }\end{array}$ & $\begin{array}{l}\text { Object } \\
\text { ive }\end{array}$ & $\begin{array}{l}\text { Relative } \\
\text { weight }\end{array}$ & $\begin{array}{l}\text { R e la t i v e } \\
\text { weight of P } \\
\text { as compared } \\
\text { with Q }\end{array}$ \\
\hline$P_{1}$ & 0.093 & $Q_{11}$ & 0.167 & 0.016 \\
\hline & & $Q_{12}$ & 0.833 & 0.078 \\
\hline$P_{2}$ & 0.325 & $Q_{21}$ & 0.115 & 0.037 \\
\hline & & $Q_{22}$ & 0.480 & 0.156 \\
\hline & & $Q_{23}$ & 0.405 & 0.132 \\
\hline$P_{3}$ & 0.373 & $Q_{31}$ & 0.525 & 0.196 \\
\hline & & $Q_{32}$ & 0.334 & 0.124 \\
\hline & & $Q_{33}$ & 0.142 & 0.053 \\
\hline$P_{4}$ & 0.209 & $Q_{41}$ & 0.500 & 0.105 \\
\hline & & $Q_{42}$ & 0.250 & 0.052 \\
\hline & & $Q_{43}$ & 0.250 & 0.052 \\
\hline
\end{tabular}

\section{(3) Consistency test}

The relative weight of $\mathrm{O}$ as compared with $P_{i}=\left(P_{1}, P_{2}, P_{3}, P_{4}\right)^{T}$ would be:

$$
W_{P}=\left(W_{P_{1}}, W_{P_{2}}, W_{P_{3}}, W_{P_{4}}\right)^{T}=(0.093,0.325,0.373,0.209)^{T}
$$

The next step is to compute the maximum Eigen value and perform consistency's test.

$$
O_{-P} W_{P}=\left|\begin{array}{lccc}
1 & 0.333 & 0.250 & 0.500 \\
3 & 1 & 0.5 & 3 \\
4 & 2 & 1 & 1 \\
2 & 0.333 & 1 & 1
\end{array}\right|\left[\begin{array}{l}
0.093 \\
0.325 \\
0.373 \\
0.209
\end{array}\right]=\mid \begin{aligned}
& 0.399 \\
& 1.394 \\
& 1.557 \\
& 0.829
\end{aligned}
$$

$$
C I=\frac{\lambda_{\max }-n}{n-1}=0.0596
$$

According to the table 4 , the value of RI would be:

$$
\begin{aligned}
& R I=0.90 \\
& C R=\frac{C I}{R I}=0.0662<0.1
\end{aligned}
$$

The consistency of matrix is acceptable.

The relative weight of $P_{1}$ as compared with $Q_{1}=\left(Q_{11}, Q_{12}\right)^{T}$ would be:

$W_{Q_{1}}=\left(W_{Q_{11}}, W_{Q_{12}}\right)^{T}=(0.167,0.833)^{T}$

$C I=0.000$

The consistency of matrix is acceptable.

The relative weight of $P_{2}$ as compared with $Q_{2}=\left(Q_{21}, Q_{22}, Q_{23}\right)^{T}$ would be:

$W_{Q_{2}}=\left(W_{Q_{21}}, W_{Q_{22}}, W_{Q_{23}}\right)^{T}=(0.115,0.480,0.405)^{T}$

$\lambda_{\max }=3.029$

$C I=0.015$

$R I=0.58$

$C R=0.0259<0.1$ 
The consistency of matrix is acceptable.

The relative weight of $P_{3}$ as compared with $Q_{3}=\left(Q_{31}, Q_{32}, Q_{33}\right)^{T}$ would be:

$W_{Q_{3}}=\left(W_{Q_{31}}, W_{Q_{32}}, W_{Q_{33}}\right)^{T}=(0.525,0.334,0.142)^{T}$

$\lambda_{\max }=3.054$

$C I=0.027$

$R I=0.58$

$C R=0.0466<0.1$

The consistency of matrix is acceptable.

The relative weight of $P_{4}$ as compared with $Q_{4}=\left(Q_{41}, Q_{42}, Q_{43}\right)^{T}$ would be:

$W_{Q_{4}}=\left(W_{Q_{41}}, W_{Q_{42}}, W_{Q_{43}}\right)^{T}=(0.500,0.250,0.250)^{T}$

$\lambda_{\max }=3.000$

$C I=0.000$

The consistency of matrix is acceptable.

The relative weight of $\mathrm{P}$ as compared with

$Q=\left(Q_{11}, Q_{12}, Q_{21}, Q_{22}, Q_{23}, Q_{31}, Q_{32}, Q_{33}, Q_{41}, Q_{42}, Q_{43}\right)^{T}$ would be:

$W_{Q}=\left(W_{Q_{11}}, W_{Q_{12}}, W_{Q_{21}}, W_{Q_{22}}, W_{Q_{23}}, W_{Q_{31}}, W_{Q_{32}}, W_{Q_{33}}\right.$,

$\left.W_{Q_{41}}, W_{Q_{42}}, W_{Q_{43}}\right)^{T}=(0.016,0.078,0.037,0.156,0.132,0.196,0.124$, $0.053,0.105,0.052,0.052)^{T}$

$C I=(0.093 \times 0.0)+(0.325 \times 0.015)+(0.373 \times 0.027)$

$+(0.209 \times 0.0)=0.0150$

$R I=(0.093 \times 0.00)+(0.325 \times 0.58)+(0.373 \times 0.58)$

$+(0.209 \times 0.58)=0.526$

$C R=0.0285<0.1$

The consistency of matrix is acceptable.

(4) Choosing and analysis of $\mathrm{S}, \mathrm{W}$ from internal environment factor system

In this part, I also refer to importance score of preliminary female officers from the survey. Then I combine the importance values with the weights and gained the compositive weights of internal environment factors as following table19.

Table 19 Evaluation of internal environment factors

\begin{tabular}{|c|c|c|c|}
\hline $\begin{array}{c}\text { Internal } \\
\text { environment }\end{array}$ & Weight & $\begin{array}{c}\text { Importance } \\
\text { score }\end{array}$ & $\begin{array}{c}\text { Compositive } \\
\text { weight }\end{array}$ \\
\hline$Q_{11}$ & 0.016 & -1 & -0.02 \\
\hline$Q_{12}$ & 0.078 & -5 & -0.39 \\
\hline$Q_{21}$ & 0.037 & 5 & 0.19 \\
\hline$Q_{22}$ & 0.156 & -5 & -0.78 \\
\hline$Q_{23}$ & 0.132 & 3 & 0.40 \\
\hline$Q_{31}$ & 0.196 & 3 & 0.59 \\
\hline$Q_{32}$ & 0.124 & 3 & 0.37 \\
\hline$Q_{33}$ & 0.053 & 5 & 0.26 \\
\hline$Q_{41}$ & 0.105 & 0 & 0.00 \\
\hline
\end{tabular}

\begin{tabular}{|l|l|l|l|}
\hline$Q_{42}$ & 0.052 & 0 & 0.00 \\
\hline$Q_{43}$ & 0.052 & 0 & 0.00 \\
\hline
\end{tabular}

There are 11 internal environment factors of preliminary female officers. According to preliminary female officers opinions, there are 4 secondary influence factors and they are debarred in Table19. The rest factors are major influence factors. They are as below.

$Q_{12}(-0.39), Q_{21}(0.19), Q_{22}(-0.78), Q_{23}(0.40), Q_{31}(0.59)$, $Q_{32}(0.37), Q_{33}(0.26)$.

$Q_{21}(0.19), Q_{23}(0.40), Q_{31}(0.59), Q_{32}(0.37), Q_{33}(0.26)$ is chosen to be $\mathrm{S}$ (strength). $Q_{12}(-0.39), Q_{22}(-0.78)$ are chosen to be $\mathrm{W}$ (weakness) as following Table20.

Table 20 Analysis of internal environmental factors

\begin{tabular}{|c|c|}
\hline \multicolumn{2}{|r|}{ Strength } \\
\hline Strategic Factors & Remark \\
\hline $\begin{array}{l}\text { Professional } \\
\text { knowledge }\end{array}$ & $\begin{array}{l}\text { There is no gap between female } \\
\text { and male students in all courses of } \\
\text { major. Even some female students } \\
\text { is getting higher grade than male } \\
\text { ones. }\end{array}$ \\
\hline Practical Ability & $\begin{array}{l}\text { When happened some difficulties in } \\
\text { working, this is studying the } \\
\text { working knowledge, finding out the } \\
\text { problems and suggesting the } \\
\text { efficient solutions as soon as } \\
\text { possible. }\end{array}$ \\
\hline Understanding & $\begin{array}{l}\text { When they got some orders, they } \\
\text { can figure out the specific situation } \\
\text { and understand masters' orders. }\end{array}$ \\
\hline Expression & $\begin{array}{l}\text { When they communicate in a } \\
\text { independent place, they can express } \\
\text { their opinion logically, calmly and } \\
\text { in detail and even they can } \\
\text { understand masters' intention in } \\
\text { writing and speaking. }\end{array}$ \\
\hline Judgement & $\begin{array}{l}\text { They can figure out many kinds of } \\
\text { policies, orders, guidelines and } \\
\text { apply for proper decisions. }\end{array}$ \\
\hline \multicolumn{2}{|r|}{ Weakness } \\
\hline Strategic Factors & Remark \\
\hline Continuity of Job & $\begin{array}{l}\text { Women need to get some period for } \\
\text { childbirth and child care. In this } \\
\text { period, they can be obliged to quit } \\
\text { the job as a seafarer. }\end{array}$ \\
\hline $\begin{array}{l}\text { Working } \\
\text { Capability }\end{array}$ & $\begin{array}{l}\text { Especially, female engineers can } \\
\text { feel biological limitation as getting } \\
\text { higher grade onboard. }\end{array}$ \\
\hline
\end{tabular}




\section{SWOT analysis of the strategy combination}

This paper is applied SWOT analysis to figure out the activation strategy for preliminary female officers. SWOT analysis is a strategic planning method used to evaluate the strengths, weaknesses, opportunities, and threats involved in researches. It involves specifying the objective of the research and identifying the internal and external factors that favorable and unfavorable to achieving that objective as following Table21.

Table 21 SWOT strategy combination of preliminary female officers

\begin{tabular}{|c|c|}
\hline S.O. Strategy & W.O. Strategy \\
\hline $\begin{array}{l}\text { (1)Make full use of } \\
\text { professional knowledge and } \\
\text { practical ability for } \\
\text { working onboard. } \\
\text { (2) Make put emphasis job } \\
\text { performance. } \\
\text { (3)Develop the } \\
\text { attractiveness of the job as } \\
\text { female maritime officers. }\end{array}$ & $\begin{array}{l}\text { (1)Establish the information } \\
\text { platform to meet the need } \\
\text { for the shipping companies } \\
\text { (2)Raise the power to } \\
\text { endure working capability } \\
\text { on field works } \\
\text { (3)Improve education } \\
\text { system for female maritime } \\
\text { officers based on various } \\
\text { international policy of them } \\
\text { as active as possible. }\end{array}$ \\
\hline S.T. Strategy & W.T. Strategy \\
\hline $\begin{array}{l}\text { (1) Emphasize the excellent } \\
\text { female students' grade. } \\
\text { (2) Improve international } \\
\text { policies for female } \\
\text { maritime officers for } \\
\text { domestic circumstances in } \\
\text { Korea. } \\
\text { (3) Strengthen cooperation } \\
\text { among graduates, shipping } \\
\text { companies and government. }\end{array}$ & $\begin{array}{l}\text { (1) By dint of women, } \\
\text { strive for own development } \\
\text { (2) Introduce advanced } \\
\text { management ideas from } \\
\text { foreign countries. } \\
\text { (3) Speed up the } \\
\text { transformation of education } \\
\text { system. } \\
\text { (4) Strengthen the career } \\
\text { path from onboard to land. }\end{array}$ \\
\hline
\end{tabular}

The growing shortage of seafarers has become an issue of global concern. This is especially evident in light of the recent rapid growth of the maritime industry. According to the influential BIMCO/ISF Manpower Update 2005 an anticipated shortage of some 27,000 maritime officers worldwide is forecasted by the year 2015. Various factors have been observed in the world economy between 2005 2010, which have influenced the future supply of seafarers(JITI \& NF, 2010). Due to this circumstances, the advent of female officers is an extremely encouraging phenomenon

\section{Conclusion}

This paper is to suggest the activation strategy for female officers in Korean maritime industry applied to AHP and SWOT analysis. As a result, it was concluded as follows.

First of all, make full use of female maritime officers' superior aspects by using professional knowledge, practical ability, job performance.

Secondly, make attractiveness the job "maritime officers". Although money may have emerged as the highest single factor what motivated seafarers to stay at sea for a long time, it is, nevertheless, instructive to note that job satisfaction, career-related ambition and job security all scored highly and, collectively, outscored purely financial considerations. The idea that the maritime industry including government and education institutions can provide the basis for a fulfilling and satisfying life-long career as a woman is borne out by the responses to whether a career at sea was viewed as a job for life.

Thirdly, improve the maritime education system for female students. Working onboard highly depends on strong spirit as well as the strong physical condition. The education system has to include specialized training programs and the measures for harassment using advanced solution from other industry and countries.

Fourthly, strengthen the career path for female maritime officers. As the aforementioned of present female maritime officers status, the number of them who can engage in the boarding works was relatively limited. This paper went one step forward, it insisted the new career path for preliminary female maritime officers which include the shipyard, classification society, engine-parts manufactures and so on based on sound network between female graduates and students.

Finally, speed up the responding to changes. Education institution must speed up the education system responding to global situation. They already sent out over 1,200 graduates but there is not the appropriate policy for them to survive in maritime industry. 


\section{References}

[1] Ali Gorener(2012), "Comparing AHP and ANP: An Application of Strategic Decisions Making in a Manufacturing Company", International Journal of Business and Social Science, Vol. 3 No. 11, pp. 194-207.

[2] Australian Maritime College(2009), A Review of some solutions to the shortage of maritime skills, Barrie Lewarn Maritime Transport Policy Center, pp. 10-20.

[3] Delphi method, http://www.wikipedia.org.(2013)

[4] Japan International Transport Institute and The Nippon Foundation(2010), A Study on the Future Global Supply and Demand for Seafarers and Possible Measures to Facilitate Stakeholder to Secure a Quantity of Quality Seafarers, pp. 13-16.

[5] Jo, S. H.(2011), “Towards a Development Strategy for the Recruitment and Retention of Women Seafarers in Cargo Ships with Particular Reference to the Republic of Korea”, Journal of Navigation and Port Research International Edition, Vol. 35, No. 2, pp. 137-147.

[6] Jo, S. H.(2013), "Investigation of Awareness on Female Maritime Seafarers as a Job", 2013 Joint Conference KINPR \& KOSME proceedings(Republic of Korea Naval Academy, 27th-28th Jun, 2013, pp. 242-244.

[7] Lee, Y. C.(1999), "A Study on the Reasonable Protective System for Female Officers as Seafarers", Collection of Dissertations in Research Institute of Maritime Industry, pp. 5-36.

[8] Michelle A. T.(2003), "Sexual Health of Women Working aboard Cruise Ships", Health Education Journal, Vol. 62, No. 4, pp. 293-303.

[9] Park, J. S.(2013), "Present State and Challenges for Women Seafarers in Korea", 2013 Joint Conference KINPR \& KOSME proceedings(Republic of Korea Naval Academy, 27th-28th Jun, 2013), pp. 239-241.

[10] Park, Y. S.(2012), Making Decision based on AHP, Kyo Woo Sa, pp. 91-118.

Received 17 January 2014

Revised 13 February 2014

Accepted 14 February 2014 